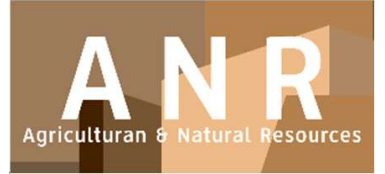

PAPER - OPEN ACCESS

\title{
Pengaruh Ketebalan Mulsa Ampas Tebu Dan Interval Penyiraman Terhadap Pertumbuhan Tanaman Sukun (Artocarpus communis Forst)
}

\author{
Author : : Afifuddin Dalimunthe dkk., \\ DOI $\quad: 10.32734 /$ anr.v3i1.837 \\ Electronic ISSN : :2654-7023 \\ Print ISSN : $2654-7015$
}

Volume 3 Issue 1-2020 TALENTA Conference Series: Agriculturan \& Natural Resource (ANR)

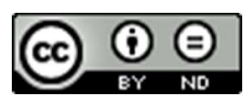

This work is licensed under a Creative Commons Attribution-NoDerivatives 4.0 International License.

Published under licence by TALENTA Publisher, Universitas Sumatera Utara

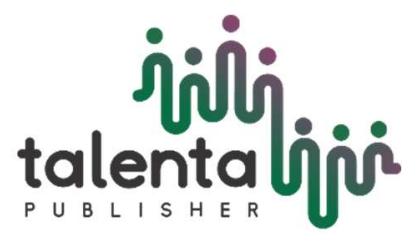




\section{Pengaruh Ketebalan Mulsa Ampas Tebu Dan Interval Penyiraman Terhadap Pertumbuhan Tanaman Sukun (Artocarpus communis Forst)}

\author{
Afifuddin Dalimunthe ${ }^{\mathrm{a}}$, Budi Utomo ${ }^{\mathrm{a}}$, dan Ratih Fransiska ${ }^{\mathrm{a}}$ \\ ${ }^{a}$ Program Studi Kehutanan, Fakultas Kehutanan, Universitas Sumatera Utara, Jl. Tri Dharma Ujung No. 1 Kampus USU Medan 20155, Indonesia \\ afifuddindalimunthe@yahoo.co.id
}

\begin{abstract}
Abstrak
Breadfruit (Artocarpus communis Forst) is a plant that has many benefits, which is able to support the welfare of the community. To cultivate these plants required effective and efficient techniques. This study aims to determine the effect of bagasse mulch thickness and intervals of watering to growth of breadfruit. This study used a complete randomized design (RAL) with 2 factors. The first factor is the thickness factor of bagasse mulch (T) which consists of control/without treatment (T0), thickness $1 \mathrm{~cm}(\mathrm{~T} 1)$, thickness $3 \mathrm{~cm}$ (T2) and thickness $5 \mathrm{~cm}$ (T3) and the second factor is watering interval (S) consisting of daily watering (S1), 1 time in 3 days (S2) and 1 time in 6 days (S3). The observed parameters were height increase (cm), diameter (cm), number of leaves (strands), length of root $(\mathrm{cm})$, upper water content of plants (shoot) $(\%)$ and moisture content (root)(\%). The results showed that there is a real effect on the growth of breadfruit with the treatment of various of bagasse mulch thickness to height increase, diameter, number of leaves, length of root, and upper water content of plants. And the treatment of watering interval showed the real effect on the parameters of height increase, diameter, number of leaves and length of root.
\end{abstract}

Keywords: breadfruit; mulch bagasse; watering interval

\section{Pendahuluan}

Sukun merupakan tanaman yang memiliki banyak manfaat baik dari dari segi ekologi maupun segi ekonomi. Dari segi ekologi sukun memiliki tajuk yang rindang dan perakaran yang dalam yang dapat menyebar luas, sehingga dapat direkomendasikan untuk kegiatan penghijauan dan konservasi lahan. Secara ekonomi, sukun dapat dimanfaatkan buah, daun dan kayunya dimana hal tersebut dapat meningkatkan kesejahteraan masyarakat. Buah sukun dapat dijadikan bahan makanan pokok alternatif sebagai pengganti beras. Manfaat lain dari sukun adalah kayunya yang sudah tua dapat digunakan sebagai bahan bangunan (kontruksi ringan), papan yang dikilapkan, bahan pembuatan kotak/peti, mainan dan bahan baku pulp. Tanaman sukun tidak menghasilkan biji dalam buahnya atau partinokarpi, sehingga hanya dapat dibiakkan secara vegetatif. Teknik-teknik pembibitan yang dapat dilakukan adalah penanaman tunas akar, pencangkokan, penempelan tunas atau okulasi dan stek akar [1].

Media tanam merupakan komponen utama dalam bercocok tanam. Media tanam yang akan digunakan harus disesuaikan dengan jenis tanaman yang ingin ditanam. Secara umum, media tanam harus dapat menjaga kelembapan daerah sekitar akar, menyediakan cukup udara, dan dapat menyediakan unsur hara. Media tumbuh yang baik harus memenuhi beberapa persyaratan, yaitu tidak terlalu padat, sehingga dapat membantu pembentukan dan perkembangan 
akar tanaman. Selain itu, juga mampu menyimpan air dan unsur hara secara baik, mempunyai aerase yang baik, tidak menjadi sumber penyakit serta mudah didapat dengan harga yang relatif murah [2].

Air memiliki peran penting dalam proses pertumbuhan tanaman. Kekurangan air dapat mempengaruhi semua proses pertumbuhan tanaman baik proses fisiologi, biokimia, anatomi dan morfologi. Pada proses fisiologi, tanaman yang mengalami kekurangan air akan mengalami penurunan kosentrasi klorofil daun yang dapat menyebabkan terhambatnya pembentukan klorofil, penurunan enzim rubisco dan terhambatnya penyerapan unsur hara, terutama nitrogen dan magnesium yang berperan penting dalam sitesis klorofil [3].

Aplikasi penggunaan mulsa dapat meningatkan pertumbuhan dan hasil tanaman. Hal tersebut dikarenakan pengaplikasian mulsa dapat meningkatkan dan mempertahankan kelembaban tanah, menurunkan suhu tanah tanah agar tetap stabil pada suhu rendah dan dapat mengurangi kompetisi antara tanaman dengan gulma. Aplikasi mulsa bermanfaat untuk melindungi agregat tanah dari kerusakan oleh terpaan air hujan, penyerapan air oleh tanah, mengurangi kecepatan aliran permukaan, mengurangi laju evaporasi dan mengendalikan pertumbuhan gulma secara efektif [4]. Ampas tebu atau lazimnya disebut bagas, adalah hasil samping dari proses ekstraksi (pemerahan) cairan tebu. Selama ini pemanfaatan ampas tebu (sugar cane bagasse) yang dihasilkan masih terbatas dan hanya digunakan untuk makanan ternak, bahan baku pembuatan pupuk (kompos), pulp, particle board dan untuk bahan bakar boiler di pabrik gula [5].

\subsection{Tujuan Penelitian}

Tujuan penelitian ini untuk mengevaluasi pengaruh ketebalan mulsa ampas tebu dan interval penyiraman terhadap pertumbuhan tanaman sukun (A. communis Forst).

\subsection{Hipotesis}

1. Perlakuan berbagai ketebalan mulsa ampas tebu berpengaruh terhadap pertumbuhan tanaman sukun $(A$. communis Forst).

2. Perlakuan interval penyiraman yang berbeda terhadap pertumbuhan sukun (A. communis Forst).

3. Interaksi antara berbagai ketebalan mulsa ampas tebu dan interval penyiraman terhadap pertumbuhan sukun $(A$. communis Forst).

\subsection{Manfaat Penelitian}

Penelitian ini berguna untuk mendapatkan informasi dalam penggunaan ketebalan mulsa ampas tebu dan interval penyiraman yang tepat untuk pertumbuhan tanaman sukun (A. communis Forst).

\section{Metode Penelitian}

\subsection{Lokasi dan Waktu Penelitian}

Penelitian ini dilaksanakan di Rumah Kaca Fakultas Pertanian, Universitas Sumatera Utara, Medan. Penelitian ini dilaksanakan pada bulan April 2018 sampai dengan Juni 2018.

\subsection{Bahan dan Alat}

Bahan yang digunakan dalam penelitian ini adalah bibit sukun (A. communis Forst), mulsa ampas tebu, top soil, polybag dengan ukuran $20 \times 20 \mathrm{~cm}$ dan kertas label. Alat yang digunakan dalam penelitian ini adalah alat tulis, spidol, cangkul, kalkulator, kamera, gunting, penggaris, califer, benang, oven, cutter, kertas koran, timbangan analitik dan software microsoft excel. 


\subsection{Rancangan Penelitian}

Percobaan ini dilakukan dengan menggunakan Rancangan Acak Lengkap (RAL) faktorial dua faktor yaitu:

Faktor $\mathrm{T}$ untuk ketebalan mulsa ampas tebu yang terdiri 4 jenis perlakuan, yaitu:

$\mathrm{T}_{0}:$ Kontrol (Tanpa Perlakuan)

$\mathrm{T}_{1}:$ Ketebalan $1 \mathrm{~cm}$

$\mathrm{T}_{2}$ : Ketebalan $3 \mathrm{~cm}$

$\mathrm{T}_{3}$ : Ketebalan $5 \mathrm{~cm}$

Faktor $\mathrm{S}$ untuk interval penyiraman yang terdiri 3 perlakuan, yaitu:

$\mathrm{S}_{1}$ : Setiap hari

$\mathrm{S}_{2}: 1$ kali dalam 3 hari

$\mathrm{S}_{3}$ : 1 kali dalam 6 hari

Semua perlakuan diulang sebanyak 3 kali sehingga diperoleh 36 jumlah unit percobaan.

Model linier rancangan yang digunakan sebagai berikut:

$$
Y_{i j k} \quad=\mu+\alpha_{i}+\beta j+(\alpha \beta)_{i j}+\sum i j k
$$

$\mathrm{Y}_{\mathrm{ijk}}=$ respon pengamatan untuk pemberian mulsa ampas tebu pada ketebalan ke-i interval penyiraman ke-j ulangan ke-k

$\mu \quad=$ rataan umum pertumbuhan sukun

$\alpha_{\mathrm{i}} \quad=$ pengaruh pemberian mulsa ke-i

$\beta \quad=$ pengaruh interval penyiraman ke-j

$(\alpha \beta)_{\mathrm{ij}}=$ interaksi antara pemberian mulsa ampas tebu dengan interval penyiraman

$\sum i j k=$ pengaruh galat pada pemberian mulsaampas tebu ketebalan ke i interval penyiraman ke-j ulangan ke-k.

\subsection{Prosedur Penelitian}

\subsubsection{Pengadaan Bibit Sukun (A. communis Forst)}

Bibit sukun (A. communis Forst) yang digunakan pada penelitian ini adalah bibit yang berumur seragam yaitu 6 bulan dan memiliki kondisi fisik yang sehat (tidak rusak). Bibit sukun tersebut berasal dari Tanjung Morawa.

\subsubsection{Menyediakan Media Tanam}

Media tanam yang digunakan pada penelitian ini adalah polybag yang berisi top soil. Top soil yang digunakan pada penelitian ini merupakan top soil tanah kritis yang berasal pada Arboretum Kuala Bekala, Universitas Sumatera Utara.

\subsubsection{Penanaman Bibit Sukun}

Bibit sukun ditanam kedalam polybag yang telah berisi top soil, kemudian beri label nama pada polybag sesuai dengan perlakuan yang diberikan pada tanaman.

\subsubsection{Pemberian mulsa ampas tebu}

Mulsa ampas tebu diberikan setelah bibit ditanam dalam polybag dengan cara meletakkan ampas tebu diatas permukaan tanah di sekeliling tanaman sesuai dengan perlakuan yang diberikan.

\subsection{Parameter Pengamatan}

Sebelum dilakukan pengamatan parameter, dilakukan terlebih dahulu pengambilan data awal pada beberapa parameter. Jadi data yang diperoleh selama pengukuran akhir parameter dikurang dengan data awal. Pengamatan mulai dilakukan seminggu setelah tanam (telah melewati masa adaptasi/aklimatisasi). Pengamatan dilakukan selama 3 (tiga) bulan, parameter yang diamati, yaitu: 


\subsubsection{Pertambahan tinggi $(\mathrm{cm})$}

Tinggi tanaman sukun diukur dari pangkal hingga titik tumbuh tertinggi tanaman menggunakan benang dan penggaris. Pengukuran tinggi tanaman diukur setiap 2 minggu sekali.

\subsubsection{Diameter batang $(\mathrm{cm})$}

Diameter batang diukur menggunakan califer pada bagian pangkal tanaman yang telah diberi tanda terlebih dahulu dengan menggunakan spidol. Pengukuran diameter tanaman dilakukan setiap 2 minggu sekali.

\subsubsection{Jumlah daun (helai)}

Perhitungan jumlah daun dilakukan pada saat pengambilan data terakhir. Jumlah daun yang dihitung mulai dari daun paling bawah sampai tajuk teratas yang sudah terbuka sempurna.

\subsubsection{Panjang akar (cm)}

Pengukuran panjang akar tanaman diukur pada akhir pengamatan dengan penggaris. Dimana akar primer yang diukur mulai dari pangkal sampai ujung akar terpanjang pada tanaman tersebut.

\subsubsection{Kadar air tanaman (\%)}

Kadar air tanaman dihitung pada akhir pengamatan dengan menimbang bagian atas dan bagian bawah tanaman pada setiap perlakuan. Untuk perhitungan kadar air tanaman dilakukan dengan menggunakan oven pada suhu $103 \pm$ $2{ }^{\circ} \mathrm{C}$ sampai beratnya konstan. Untuk kadar air bagian atas (shoot) diindikatorkan dari pangkal sampai tajuk tanaman dan kadar air bagian bawah (root) diindikatorkan dari pangkal sampai ujung akar. Perhitungan kadar air diformulasikan dengan rumus:

$$
\text { Kadar air }=\frac{\text { Berat Awal-Berat Akhir }}{\text { Berat awal }} \times 100 \%
$$

\section{Hasil dan Pembahasan}

\subsection{Hasil}

\subsubsection{Pertambahan tinggi $(\mathrm{cm})$}

Hasil pengukuran pertambahan tinggi rata-rata sukun (A. communis Forst) selama tiga bulan tersaji pada Tabel 1.

Tabel 1. Data pengukuran pertambahan tinggi $(\mathrm{cm})$ tanaman sukun dengan perlakuan berbagai ketebalan mulsa ampas tebu dan interval penyiraman.

\begin{tabular}{llllll}
\hline Perlakuan & T0 & T1 & T2 & T3 & Rata-rata \\
\hline S1 & 1,22 & 1,27 & 1,45 & 1,85 & $1,34 \mathrm{~b}$ \\
S2 & 0,50 & 0,53 & 0,75 & 0,82 & $0,63 \mathrm{a}$ \\
S3 & 0,34 & 0,71 & 0,70 & 0,75 & $0,59 \mathrm{a}$ \\
\hline Rata-rata & 0,69 & 0,84 & 0,83 & 1,11 &
\end{tabular}

Keterangan : Angka-angka yang diikuti oleh huruf yang sama pada kolom rataan ketebalan mulsa ampas tebu, pada baris rataan interval penyiraman dan pada baris dan kolom pada interaksi antara ketebalan mulsa sama berarti berbeda tidak nyata menurut uji DMRT pada taraf $\alpha$ 5\%.

Data hasil pengukuran pertambahan tinggi $(\mathrm{cm})$ pada Tabel 1 menunjukan nilai rata-rata tinggi tanaman tertinggi terdapat pada perlakuan T3S1 yaitu kombinasi perlakuan ketebalan mulsa $5 \mathrm{~cm}$ (T3) dengan penyiram setiap hari (S1) yaitu $1,85 \mathrm{~cm}$. Sedangkan data tinggi tanaman terendah terdapat pada perlakuan control (T0) /tanpa perlakuan dengan interval penyiraman setiap 6 hari kali $(\mathrm{S} 3)$ yaitu $0,34 \mathrm{~cm}$. Berdasarkan hasil sidik ragam pengamatan pertambahan tinggi $(\mathrm{cm})$ menjelaskan bahwa ada pengaruh tidak nyata pada perlakuan berbagai ketebalan mulsa ampas tebu terhadap pertumbuhan tanaman sukun dan pada perlakuan interval penyiraman yang berbeda, ada pengaruh yang nyata terhadap pertumbuhan tinggi tanaman sukun (A. communis Forst). 


\subsubsection{Pertambahan Diameter Batang (cm)}

Data pengamatan pertambahan diameter batang $(\mathrm{cm})$ sukun tersaji pada Tabel 2.

Tabel 2. Data pengukuran diameter $(\mathrm{cm})$ tanaman sukun dengan perlakuan mulsa ampas tebu dan interval penyiraman.

\begin{tabular}{llllll}
\hline Perlakuan & T0 & T1 & T2 & T3 & Rata-rata \\
\hline S1 & 0,016 & 0,019 & 0,015 & 0,014 & 0,016 \\
S2 & 0,010 & 0,009 & 0,010 & 0,008 & 0,009 \\
S3 & 0,013 & 0,009 & 0,006 & 0,016 & 0,011 \\
\hline Rata-rata & 0,013 & 0,012 & 0,010 & 0,013 & \\
\hline
\end{tabular}

Keterangan: Angka-angka yang diikuti oleh huruf yang sama pada kolom rataan ketebalan mulsa ampas tebu, pada baris rataan interval penyiraman dan pada baris dan kolom pada interaksi antara ketebalan mulsa sama berarti berbeda tidak nyata menurut uji DMRT pada taraf $\alpha 5 \%$.

Berdasarkan Tabel 2, dapat diketahui bahwa pengamatan pengukuran diameter $(\mathrm{cm})$ tanaman sukun menunjukan bahwa ada perbedaan tidak nyata pada setiap perlakuan, baik perlakuan pemberian berbagai ketebalan mulsa ampas tebu maupun perlakuan beda penyiraman. Diameter tanaman sukun terbesar terdapat pada perlakuan pemberian mulsa ampas tebu dengan ketebalan $1 \mathrm{~cm}$ (T1) dengan kombinasi penyiraman setiap hari (S1) dengan nilai 0,019 cm sedangkan diameter terkecil terdapat pada tanaman sukun dengan perlakuan pemberian mulsa ampas tebu dengan ketebalan $3 \mathrm{~cm}$ (T2) dengan kombinasi penyiraman 6 hari satu kali (S3) dengan nilai 0,006 cm.

\subsubsection{Jumlah Daun (helai)}

Perhitungan parameter jumlah daun dilakukan dilakukan pada akhir penelitian dikarenakan jumlah daun mengalami pengurangan (gugur) dan penambahan akibat proses fotosintesis. Adapun data perhitungan jumlah daun (helai) pada akhir penelitian dapat dilihat pada Tabel 3.

Hasil sidik ragam menunjukkan bahwa ketebalan mulsa ampas tebu tidak berpengaruh nyata terhadap pertumbuhan sukun. Akan tetapi, interval penyiraman berpengaruh nyata terhadap pertumbuhan sukun.

Tabel 3. Data perhitungan jumlah daun (helai) tanaman dengan perlakuan mulsa ampas tebu dan interval penyiraman

\begin{tabular}{llllll}
\hline Perlakuan & T0 & T1 & T2 & T3 & Rata-rata \\
\hline S1 & 5,67 & 5,67 & 5,67 & 6,00 & $5,75 \mathrm{c}$ \\
S2 & 4,67 & 4,33 & 4,00 & 4,67 & $4,42 \mathrm{~b}$ \\
S3 & 3,67 & 4,00 & 3,00 & 2,33 & $3,25 \mathrm{a}$ \\
\hline Rata-rata & 4,67 & 4,67 & 4,22 & 4,33 & \\
\hline
\end{tabular}

Keterangan : Angka-angka yang diikuti oleh huruf yang sama pada kolom rataan ketebalan mulsa ampas tebu, pada baris rataan interval penyiraman dan pada baris dan kolom pada interaksi antara ketebalan mulsa sama berarti berbeda tidak nyata menurut uji DMRT pada taraf $\alpha 5 \%$.

Berdasarkan hasil pengamatan, jumlah daun terbanyak terdapat perlakuan pemberian mulsa ampas tebu dengan ketebalan $5 \mathrm{~cm}$ (T3) dengan kombinasi penyiraman setiap hari (S1) dengandaun berjumlah 6 helai. Sedangkan jumlah daun terkecil terdapat pada perlakuan pemberian mulsa ampas tebu dengan ketebalan $5 \mathrm{~cm}$ (T3) dengan kombinasi penyiraman 6 hari sekali (S3) dengan nilai jumlah daun sebesar 2,33 helai.

\subsubsection{Panjang Akar (cm)}

Akar pada tanaman sukun memiliki panjang yang berbeda-beda walaupun memiliki umur yang seragam. Hal ini dapat diketahui berdasarkan tabel sidik ragam yang menyatakan bahwa ada pengaruh tidak nyata pada perlakuan berbagai ketebalan mulsa ampas tebu dan perlakuan penyiraman yang berbeda terhadap pertumbuhan sukun. Adapun data panjang akar sukun tersaji pada Tabel 4. 
Tabel 4. Data pengukuran panjang akar $(\mathrm{cm})$ tanaman dengan perlakuan mulsa ampas tebu dan interval penyiraman.

\begin{tabular}{llllll}
\hline Perlakuan & T0 & T1 & T2 & T3 & Rata-rata \\
\hline S1 & 34,33 & 39,07 & 35,20 & 43,57 & 38,04 \\
S2 & 36,27 & 33,90 & 36,77 & 40,43 & 36,84 \\
S3 & 39,83 & 27,97 & 40,10 & 39,50 & 36,85 \\
\hline Rata-rata & 36,81 & 33,65 & 37,36 & 41,17 &
\end{tabular}

Keterangan : Angka-angka yang diikuti oleh huruf yang sama pada kolom rataan ketebalan mulsa ampas tebu, pada baris rataan interval penyiraman dan pada baris dan kolom pada interaksi antara ketebalan mulsa sama berarti berbeda tidak nyata menurut uji DMRT pada taraf $\alpha$ 5\%.

Berdasarkan tabel 4, diperoleh akar terpanjang pada penelitian ini terdapat pada perlakuan pemberian mulsa dengan ketebalan $5 \mathrm{~cm}$ (T3) dengan kombinasi penyiraman setiap hari (S1) dengan nilai 43,57 cm. Sedangkan akar terpendek terdapat pada perlakuan pemberian ampas tebu dengan ketebalan $1 \mathrm{~cm}(\mathrm{~T} 1)$ dengan kombinasi penyiraman 6 hari sekali (S3) dengan nilai $27,97 \mathrm{~cm}$.

\subsubsection{Kadar Air Tanaman Bagian Atas (SHOOT) (\%)}

Kadar air suatu tanaman merupakan hasil representasi dari berat basah tanaman tanpa kadar air. Kadar air tanaman memiliki perbedaan pada setiap bagian karena timbunan hasil fotosintesis. Adapun data kadar air tanaman bagian atas (KA) tersaji pada Tabel 5.

Tabel 5. Data perhitungan kadar air tanaman bagian atas (KA) (\%) tanaman dengan perlakuan mulsa ampas tebu dan interval penyiraman.

\begin{tabular}{llllll}
\hline Perlakuan & T0 & T1 & T2 & T3 & Rata-rata \\
\hline S1 & 59,22 & 34,32 & 36,35 & 38,64 & 42,13 \\
S2 & 39,68 & 60,64 & 43,47 & 45,57 & 47,34 \\
S3 & 59,84 & 43,79 & 40,80 & 55,19 & 49,91 \\
\hline Rata-rata & 52,91 & 46,25 & 40,21 & 46,47 & \\
\hline
\end{tabular}

Keterangan : Angka-angka yang diikuti oleh huruf yang sama pada kolom rataan ketebalan mulsa ampas tebu, pada baris rataan interval penyiraman dan pada baris dan kolom pada interaksi antara ketebalan mulsa sama berarti berbeda tidak nyata menurut uji DMRT pada taraf $\alpha$ 5\%.

Berdasarkan hasil perhitungan kadar air tanaman sukun bagian atas dapat diketahui bahwa kadar air terbesar tanaman sukun bagian atas terdapat pada perlakuan pemberian mulsa dengan ketebalan $1 \mathrm{~cm}$ (T1) dengan kombinasi penyiraman 3 hari sekali (S2) dengan nilai 60,64\%. Sedangkan kadar air terkecil terdapat pada pelakuan pemberian mulsa ampas tebu dengan ketebalan $1 \mathrm{~cm}$ (T1) dengan kombinasi penyiraman setiap hari (S1) dengan nilai 34,32\%. Pada tabel sidik ragam bobot kering tanaman bagian atas pada perlakuan ketebalan mulsa ampas tebu terhadap pertumbuhan tanaman sukun tidak berpengaruh nyata begitu juga dengan perlakuan penyiraman yang berbeda juga tidak memberikan pengaruh nyata terhadap pertumbuhan sukun.

\subsubsection{Kadar Air Tanaman Bagian Bawah (ROOT) (\%)}

Berdasarkan tabel sidik ragam kadar air tanaman bagian bawah menunjukkan bahwa perlakuan pemberian berbagai ketebalan mulsa ampas tebu tidak berpengaruh nyata terhadap pertumbuhan tanaman sukun. Akan tetapi pada perlakuan penyiraman yang berbeda memberikan pengaruh nyata terhadap pertumbuhan sukun.

Kadar air tanaman tertinggi pada bagian bawah terdapat pada perlakuan tanpa pemberian mulsa ampas tebu (kontrol) (T0) dengan kombinasi penyiraman 6 hari sekali (S3) yaitu sebesar 70,11\% sedangkan kadar air tanaman bagian bawah terkecil terdapat pada perlakuan pemberian mulsa ampas tebu dengan ketebalan $3 \mathrm{~cm}(\mathrm{~T} 2)$ dengan kombinasi penyiraman setiap hari (S1) yaitu dengan nilai 29,22\%. Uji lanjutan DMRT dengan taraf $\alpha$ 5\% dilakukan pada perlakuan penyiraman. Data perhitungan kadar air tanaman bagian bawah tersaji pada Tabel 6. 
Tabel 6. Data perhitungan kadar air tanamaan bagian bawah (KB) (\%) tanaman dengan perlakuan mulsa ampas tebu dan interval penyiraman

\begin{tabular}{llllll}
\hline Perlakuan & T0 & T1 & T2 & T3 & Rata-rata \\
\hline S1 & 33,29 & 30,82 & 29,22 & 40,71 & $33,51 \mathrm{a}$ \\
S2 & 49,15 & 52,30 & 46,41 & 39,70 & $46,89 \mathrm{~b}$ \\
S3 & 70,11 & 37,12 & 40,32 & 53,56 & $50,28 \mathrm{~b}$ \\
\hline Rata-rata & 50,85 & 40,08 & 38,65 & 44,66 &
\end{tabular}

Keterangan : Angka-angka yang diikuti oleh huruf yang sama pada kolom rataan ketebalan mulsa ampas tebu, pada baris rataan interval penyiraman dan pada baris dan kolom pada interaksi antara ketebalan mulsa sama berarti berbeda tidak nyata menurut uji DMRT pada taraf $\alpha$ 5\%.

\subsubsection{Koefisien Korelasi}

Koefisien korelasi bertujuan untuk mengukur seberapa kuat atau seberapa dekat suatu relasi yang terjadi antar variabel atau parameter yang satu dengan yang lain. Analisis korelasi pada pengamatan pertambahan pertumbuhan sukun tersaji pada Tabel 7.

Tabel 7. Data perhitungan koefisien korelasi pada pertumbuhan sukun dengan perlakuan pemberian mulsa ampas tebu dan interval penyiraman.

\begin{tabular}{lllllll}
\hline & T & D & JD & PA & KA & KB \\
\hline $\mathbf{T}$ & 1 & & & & & \\
$\mathbf{D}$ & 0,024463 & 1 & & & & \\
$\mathbf{J D}$ & 0,22489 & 0,423276 & 1 & & & \\
$\mathbf{P A}$ & 0,076273 & 0,150109 & 0,006122 & 1 & 1 & \\
$\mathbf{K A}$ & 0,152611 & $-0,00867$ & $-0,37039$ & $-0,15524$ & 0,611191 & 1 \\
$\mathbf{K B}$ & $-0,23878$ & $-0,19334$ & $-0,58926$ & 0,213831 & & \\
\hline
\end{tabular}

Keterangan : T : Tinggi; D : Diameter; JD : Jumlah daun; PA : Panjang akar; KA : Kadar air tanaman bagian atas; KB : Kadar air tanaman bagian bawah

Tinggi rendahnya dan kuat lemahnya suatu korelasi pada pengamatan tergantung pada hubungan yang saling mendukung antara satu variabel dengan variabel lain. Berdasarkan data pada Tabel 7 dapat diketahui bahwa koefisien korelasi pada parameter tidak semua searah/positif. Koefisien korelasi searah/positif tertinggi/sangat kuat terdapat pada korelasi antara diameter dan jumlah daun dengan nilai 0,423276. Dimana dapat dikatakan bahwa hubungan diantara parameter pertambahan diameter $(\mathrm{cm})$ diikuti oleh pertambahan jumlah daun (helai) secara teratur dengan arah yang sama. Sedangkan koefisien korelasi negatif tertinggi terdapat pada parameter jumlah daun dengan kadar air bagian bawah (KB) bernilai -0,58926 yakni, dimana parameter kadar air tanaman bagian bawah tidak diikuti dengan pertambahan jumlah daun.

\section{Pembahasan}

Berdasarkan hasil sidik ragam, dapat diketahui bahwa perlakuan pemberian mulsa ampas tebu memiliki pengaruh tidak nyata pada pertumbuhan sukun terhadap semua parameter. Akan tetapi, perlakuan terbaik terdapat pada pemberian mulsa dengan menggunakan ketebalan mulsa $5 \mathrm{~cm}$ (T3) pada parameter tinggi $(\mathrm{cm})$, jumlah daun (helai) dan panjang akar $(\mathrm{cm})$. Hal ini sesuai dengan pernyataan [6] yang mengatakan bahwa perlakuan pemberian mulsa memberikan pengaruh yang berbeda pada setiap jenis maupun tingkat ketebalan mulsa terhadap pertumbuhan dan hasil tanaman. Mulsa sekam dengan ketebalan $8 \mathrm{~cm}$ mampu meningkatkan kadar air tanah sebesar 16,46\% dan hasil tanaman pada bobot 100 biji sebesar 10,25\% maupun bobot kering tanaman sebesar 9,04\%, jika dibandingkan dengan perlakuan tanpa mulsa.

Penggunaan mulsa ampas tebu mampu mencegah kekeringan, mengurangi laju pertumbuhan gulma dan mengurangi erosi permukaan tanah. Menurut [7], adanya mulsa di atas permukaan tanah akan menghalangi pertumbuhan benih gulma. Akibatnya tanaman yang ditanam akan bebas tumbuh tanpa kompetisi dengan gulma dalam 
penyerapan hara mineral tanah. Selain itu dengan adanya bahan mulsa di atas permukaan tanah, energi air hujan akan ditanggung oleh bahan mulsa tersebut sehingga agregat tanah tetap stabil dan terhindar dari proses penghancuran.

Perlakuan interval penyiraman memberi pengaruh nyata dalam pertumbuhan tanaman sukun terhadap parameter tinggi $(\mathrm{cm})$ dan kadar air tanaman bagian bawah (root)(\%). Penyiraman memberikan respon langsung bagi tanaman karena air memiliki peran sangat penting dalam pertumbuhan baik dalam pertambahan tinggi maupun kadar air tanaman bagian bawah. Dimana air berpengaruh terhadap rata-rata pertambahan tinggi tanaman sebagai pencerminan pertumbuhan tanaman. Meningkatnya tinggi tanaman terjadi melalui perpanjangan ruas-ruas akibat membesarnya selsel atau bertambahnya umur tanaman. Kondisi ini sesuai dengan pernyataan [8] yang menyatakan bahwa air merupakan komponen utama dalam kehidupan tanaman. Sekitar 70-90 \% berat segar tanaman adalah berupa air. Air merupakan media yang baik untuk berlangsungnya reaksi biokimia. Didalam tubuh tanaman air dapat masuk ke jaringan tanaman langsung melalui proses difusi. Proses ini dipengaruhi oleh banyak faktor diantaranya karena : 1) perbedaan kosentrasi air, dan 2) adanya faktor lingkungan yang berperan dalam proses keseimbangan air yang berada pada tanah, tanaman dan udara. Menurut [9], ketersediaan air pada tumbuhan kacang hijau berpengaruh terhadap proses fisiologis dan metabolisme dalam tanaman. Respon pertama tanaman dalam menanggapi kondisi defisit air atau cekaman air yang parah ialah dengan cara menutup stomata. Penutupan dan/atau penyempitan stomata akan menghambat proses fotosintesis. Respon yang kedua yaitu penurunan konsentrasi klorofil daun serta kekurangan air akan mempengaruhi kandungan dan organisasi klorofil dalam kloroplas pada jaringan. Pengaruh cekaman air pada pertumbuhan tanaman dicerminkan oleh daun-daun yang lebih kecil. Menurut [10], perlakuan interval waktu dan tingkat pemberian air pada tanaman kedelai memberikan pengaruh adanya interaksi terhadap variabel tinggi tanaman, jumlah daun, jumlah bunga, luas daun, jumlah biji per tanaman, jumlah polong per tanaman dan bobot polong per tanaman. Tanaman kedelai yang mendapatkan air sesuai dengan kebutuhan air tanaman yaitu perlakuan 0-75 hari sesuai kapasitas lapang (A0) mempunyai tinggi tanaman yang lebih tinggi dari perlakuan lain yang mendapatkan air dibawah kebutuhan normal atau dalam kondisi kekurangan air

Perlakuan tanpa mulsa ampas tebu atau kontrol (T0) dan penyiraman dengan interval yang cukup lama menghasilkan pertumbuhan terendah. Dapat dilihat pada data parameter diatas, dimana tinggi tanaman terendah terdapat pada perlakuan T0S3 yaitu $0,34 \mathrm{~cm}$, pada diameter terkecil terdapat pada perlakuan T2S3 dengan jumlah nilai $0,006 \mathrm{~cm}$, pada panjang akar terpendek terdapat pada perlakuan T1S3 dengan nilai 27,97 cm. Hal ini sesuai dengan pernyataan [11] yang menyatakan bahwa mulsa adalah bahan penutup tanah yang berfungsi menjaga kelembaban dan suhu tanah serta menjaga kestabilan media tanam tanaman. Mulsa juga berfungsi menekan pertumbuhan gulma sehingga tanaman akan tumbuh lebih baik. Pemberian mulsa pada permukaan tanah saat musim hujan dapat mencegah erosi pada permukaan tanah dan pemberian mulsa pada saat musim kemarau akan menahan panas matahari pada permukaan tanah bagian atas.

Sedangkan pada parameter kadar air bagian bawah, perlakuan tanpa mulsa ampas tebu dan lamanya interval penyiraman menghasilkan berat kadar air yang lebih besar karena diketahui bahwa akar pada tanaman yang kekurangan air akan terus tumbuh memanjang dan menyebarluas mencari sumber air. Hal ini sesuai dengan pernyataan [12] yang menyatakan bahwa pada saat kekurangan air, akar berperan penting dalam beradaptasi dan mengaborbsi air dengan maksimal pada sistem perakaran. Beberapa karakter morfologi akar yang menunjukan resistensi tanaman pada saat kekurangan air ialah pemanjangan akar ke lapisan tanah yang lebih dalam, pertambahan luas dan ke dalam sistem perakaran, perluasan distribusi akar secara horizontal dan vertikal, lebih besarnya berat kering akar pada genotipe tanaman yang lebih tahan kering, pertambahan volume akar, peningkatan berat jenis akar dan resistensi longitudinal pada akar, daya tembus akar yang tinggi, lebih tingginya rasio akar dan tajuk serta rasio panjang akar dan tinggi tanaman.

\section{Kesimpulan}

1. Perlakuan pemberian mulsa ampas tebu dengan berbagai ketebalan memberikan pengaruh tidak nyata terhadap parameter tinggi $(\mathrm{cm})$, diameter $(\mathrm{cm})$, jumlah daun (helai), panjang akar $(\mathrm{cm})$, kadar air tanaman bagian atas $($ shoot) $(\%)$ dan kadar air bagian bawah (root)(\%). 
2. Perlakuan berbagai interval penyiraman memberikan pengaruh nyata terhadap parameter tinggi $(\mathrm{cm})$, jumlah daun (helai), dan kadar air tanaman bagian bawah (root)(\%) dan berpengaruh tidak nyata terhadap parameter diameter $(\mathrm{cm})$, panjang akar $(\mathrm{cm})$, dan kadar air tanaman bagian atas $($ shoot $)(\%)$

3. Hasil analisis pada perlakuan pemberian berbagai ketebalan mulsa ampas tebu dan interval penyiraman berpengaruh tidak nyata terhadap pertumbuhan tanaman sukun (A. communis Forst).

\section{Referensi}

[1] Adinugraha, H. A., N. K. Kartikawati, M. D. Setiadi, dan Prastyono (2014) "Pengembangan Teknik Budidaya Sukun (Artocarpus altilis) Untuk Ketahanan Pangan", Bogor, PT. Penerbit IPP Press

[2] Aseptyo, F. R. (2013) "Pemanfaatan Ampas Tebu Dan Ampas Teh Sebagai Media Tanam Terhadap Pertumbuhan Tanaman Cabai Merah Keriting (Capsicum annum L.) Ditinjau dari Intensitas Penyiraman Air The", dalam Skripsi Universitas Muhammadiyah Surakarta, Surakarta

[3] Ai, N. S dan Y. Banyo (2011) “Konsentrasi Klorofil Daun Sebagai Indikator Kekurangan Air Pada Tanaman.” Jurnal Ilmiah Sains 11 (2): 166173.

[4] Mahmood, M., K. Farroq, A. Hussain, and R. Sher (2002) "Effect of Mulching on Growth and Yield of Potato Crop." Asian Jurnal of Plant Sci. 1 (2): 122-133

[5] Andaka, G. (2011) “Hidrolisis Ampas Tebu Menjadi Furfural dengan Katalisator Asam Sulfat.” Jurnal Teknologi 4 (2): $180-188$.

[6] Lubis, P. A., S. Y. Tyasmoro dan Sudiarso (2017) "Pengaruh Jenis dan Ketebalan Mulsa Dalam Mempertahankan Kandungan Air Tanah dan Dampaknya Terhadap Tanaman Kedelai (Glycine max L.) di Lahan Kering." Jurnal Produksi Tanaman 5 (5): 791-798.

[7] Fauzan, A. (2002) "Pemanfaatan Mulsa Dalam Pertanian Berkelanjutan.” Pertanian Organik. Malang 182-187.

[8] Suhartono, Z.M, R., A. Sidqi Zaed dan A. Khoiruddin (2008) "Pengaruh Interval Pemberian Air Terhadap Pertumbuhan dan Hasil Tanaman Kedelai (Glicie max (L) Merril) pada Berbagai Jenis Tanah.” Embryo 5 (1): 98-112.

[9] Felania, C. (2017) "Pengaruh Ketersediaan Air Terhadap Pertumbuhan Kacang Hijau (Phaceolus radiatus)." Prosiding Seminar Nasional Pendidikan Biologi dan Biologi 131-138.

[10] Nugraha, Y. S, Titin Sumarni, dan Roedy Sulistyono (2014) "Pengaruh Interval Waktu dan Tingkat Pemberian Air Terhadap Pertumbuhan dan Hasil Tanaman Kedelai (Glycine max (L) Merril.)." Jurnal Produksi Tanaman 2 (7): 552-559.

[11] Tinambunan, E., L. Setyobudi dan A. Suryanto (2014) "Penggunaan Beberapa Jenis Mulsa Terhadap Produksi Baby Wortel (Daucus carota L.) Varietas Hibrida." Jurnal Produksi Tanaman 2 (1): 25-30.

[12] Ai, N. S dan P. Torey (2013) “Karakter Morfologi Akar Sebagai Indikator Kekurangan Air Pada Tanaman.” Jurnal Bioslogos 3 (1): $31-39$. 